\title{
Transformacja własnościowa działalności przemysłowej w Polsce wedlug województw
}

\author{
UWAGI WSTĘPNE
}

Opracowanie zawiera podsumowanie badań prowadzonych przez autora w IGiPZ PAN w ramach tematu A.2.5. "Przestrzenne aspekty transformacji przemysłu w Polsce w dekadzie lat 1988-1998". Główną uwagę skupiono w badaniach na analizie przekształceń własnościowych działalności przemysłowej w skali krajowej i w poszczególnych województwach, a zwłaszcza procesu prywatyzacji, ponieważ efekty tego procesu warunkują transformację pozostałych rodzajów struktury przemysłu. Bez prywatyzacji większości działalności przemysłowej powrót do gospodarki rynkowej byłby niemożliwy. Należy podkreślić, że gospodarka rynkowa okazała się w praktyce XX w. bardziej efektywna ekonomicznie niż funkcjonująca do 1989 r. w byłym ZSRR i krajach Europy Środkowo-Wschodniej niewydolna i silnie zbiurokratyzowana gospodarka nakazowo-rozdzielcza.

Prywatyzacja przemysłu w szerokim słowa znaczeniu polega na wzroście udziału sektora prywatnego w zatrudnieniu lub wartości produkcji przemysłowej danej jednostki terytorialnej. Może to następować, gdy: 1) zatrudnienie i wartość produkcji w sektorze prywatnym w tym zakresie rosną szybciej niż w sektorze publicznym, 2) te wskaźniki przemysłu

w sektorze publicznym maleją szybciej niż w sektorze prywatnym (np. w okresie recesji), 3) w sektorze publicznym występuje stagnacja lub regres, a w sektorze prywatnym obserwować można wzrost wspomnianych wartości.

Prywatyzacja natomiast w węższym znaczeniu polega, według przepisów polskich, na przekazywaniu zakładów lub całych przedsiębiorstw przemysłowych z sektora publicznego (państwowego) do sektora prywatnego. Może to następować w formie fizycznej, tj. w drodze sprzedaży lub wydzierżawienia państwowych przedsiębiorstw lub ich części prywatnym użytkownikom - zarówno osobom fizycznym, jak i osobom prawnym, w tym spółkom pracowniczym. Może też odbywać się w formie kapitałowej, tzn. drogą komercjalizacji, a więc przekształcenia przedsiębiorstwa państwowego w spółkę akcyjną (lub z ograniczoną odpowiedzialnością) i sprzedaży akcji (albo udziałów) osobom trzecim. Działalność tych spółek jest regulowana przepisami prawa handlowego. 
W okresie PRL w powszechnym użyciu był termin przemysł uspołeczniony. Określano nim zarówno zakłady zaliczane do sektora państwowego, jak i do spółdzielczego oraz nieliczne zakłady należące do związków zawodowych, organizacji politycznych, społecznych

i religijnych. W wyniku reorganizacji zarządzania przemysłem od października 1990 roku zakłady spółdzielcze i zakłady wspomnianych organizacji zaliczane są do sektora prywatnego, a pojęcie przemysłu uspołecznionego całkowicie wyszło z użycia.

Odtąd w strukturze własnościowej przemysłu GUS wyróżnia tylko dwa główne sektory: publiczny i prywatny. Do sektora publicznego zaliczane są zakłady państwowe i samorządowe (w związku z restytucją w 1990 r. samorządów), a do sektora prywatnego wszystkie pozostałe zakłady - będące własnością zarówno osób fizycznych, jak i prawnych (spółek cywilnych, z ograniczoną odpowiedzialnością, akcyjnych i pracowniczych) oraz zakłady organizacji spółdzielczych. Oznacza to, że do wzrostu stopnia prywatyzacji przemysłu w kra-ju i w poszczególnych województwach przyczyniły się również w pewnym stopniu przekształcenia organizacyjne, zwłaszcza w przemyśle spółdzielczym.

Opracowanie obejmuje ogólną analizę tendencji i dynamiki przekształceń własnościo-wych oraz ocenę stopnia zaawansowania procesu prywatyzacji wytwórczości przemysłowej sensu largo na obszarze kraju i poszczególnych województw.

Badania oparto głównie na danych zamieszczonych w Roczniku Statystycznym GUS oraz bardziej szczegółowych danych publikowanych corocznie w latach 1989-1994 przez GUS w rocznikach pt. Zatrudnienie w gospodarce narodowej, a w latach 1995-1999 w rocznikach pt. Pracujacy $w$ gospodarce narodowej. Na podstawie danych zaczerpniętych

z tych źródeł ustalono ogólną liczbę pracujących w przemyśle (łącznie z zakładami najmniejszymi liczącymi 1-5 pracujących). Natomiast ustalenie pełnych danych o liczbie pracujących w sektorze publicznym i prywatnym w działalności przemysłowej wymagało dużo większego nakładu pracy. Trzeba było bowiem posługiwać się równocześnie danymi zawartymi w Rocznikach Statystycznych poszczególnych województw, a za ostatnie lata 1997 i 1998 także w ukazujących się co miesiąc Wojewódzkich Biuletynach Statystycznych.

W ten sposób, przy użyciu miernika liczby pracujących, ustalono dla każdego roku badanej dekady stopień zaawansowania procesu prywatyzacji całej działalności przemysłowej w poszczególnych województwach. Niestety, z powodu braku danych zagregowanych według faktycznego miejsca produkcji nie można było zastosować innych mierników przemysłu ani ustalić na obszarze województw stopnia prywatyzacji przemysłu w ścisłym słowa znaczeniu, obejmującego zakłady zatrudniające powyżej 5 pracowników. Z tego samego powodu nie udało się ustalić stopnia prywatyzacji poszczególnych gałęzi przemysłu sensu stricto w województwach.

W opracowaniu posłużono się tylko miernikiem liczby pracujących, ponieważ jedynie te dane agregowane są przez GUS i wojewódzkie urzędy statystyczne według jednostek lokalnych, czyli według faktycznego miejsca pracy. Inne mierniki przemysłu (np. wartość produkcji, wartość środków trwałych itp.) agregowane są według przedsiębiorstw, z których wiele prowadzi działalność w różnych województwach. W rezultacie cała działalność przedsiębiorstwa przemysłowego przypisana jest do jego siedziby w jednym województwie. Agregowane tą metodą dane ani nie dają rzeczywistego obrazu rozmieszczenia potencjału produkcyjnego

w przemyśle, ani nie przedstawiają faktycznego stopnia jego prywatyzacji. 
Na podstawie zgromadzonych i doprowadzonych do porównywalności danych opracowano dwie obszerne tabele, a także mapy, ilustrujące stopień zaawansowania procesu prywatyzacji działalności przemysłowej według województw w poszczególnych latach. Mapy te, dające dobry wizualny pogląd na przestrzenne zróżnicowanie efektów procesu prywatyzacji przemysłu sensu largo w Polsce, były bardzo użytecznym narzędziem badawczym.

Rolę bezpośrednich inwestycji zagranicznych w procesie prywatyzacji przemysłu polskiego przedstawiono na podstawie danych zamieszczonych w rocznych raportach o wzroście tych inwestycji, publikowanych od 1990 r. przez Instytut Koniunktur i Cen Handlu Zagranicznego pt.

Inwestycje zagraniczne $w$ Polsce. Zawarte $\mathrm{w}$ tych raportach informacje IKiCHZ opracował na podstawie danych GUS, NBP oraz szacunków PAIZ (Państwowej Agencji Inwestycji Zagranicznych). Niestety, dane te są zagregowane według siedzib firm zagranicznych w Polsce, bez podania dokładniejszej informacji o faktycznej lokalizacji inwestycji. Utrudnia to lub wręcz uniemożliwia właściwe ich zlokalizowanie na obszarze konkretnych województw.

Należy podkreślić, że w 1994 r. GUS zmienił nieco zakres pojęcia przemysł i jego klasyfikację gałęziowo-branżową, dostosowując je do Europejskiej Klasyfikacji Działalności (EKD) obowiązującej w Unii Europejskiej, do której Polska zamierza wstapić. W wyniku zmiany zakresu merytorycznego pojęcia przemysł niektóre rodzaje działalności zaliczane przedtem do przemysłu zostały przeniesione do działu (sekcji) handlu, np. zakłady naprawcze maszyn i artykułów wyposażenia gospodarstwa domowego oraz środków transportu.

Z kolei niektóre rodzaje działalności zaliczane przedtem do innych działów gospodarki zostały włączone do przemysłu, np. wydawnictwa i zakłady zaopatrzenia w wodę. Ponadto w działalności przemysłowej wyróżniono trzy sekcje: 1) górnictwo i kopalnictwo, 2) tzw. działalność produkcyjną, 3) zaopatrzenie w energię elektryczną, gaz i wodę. Zmiany te powodują, że dane o działalności przemysłowej $\mathrm{z}$ pierwszych lat transformacji (1989-1993) nie są w pełni porównywalne z danymi dotyczącymi lat 1994-1998. Toteż również z tego względu wyniki badań mają tylko przybliżony charakter.

\section{DYNAMIKA I EFEKTY PRZESTRZENNE PROCESU PRYWATYZACJI DZIAŁALNOŚCI PRZEMYSŁOWEJ W POLSCE OD 1989 R.}

W wyniku wprowadzenia do Polski po II wojnie światowej niewydolnego, centralnie zarządzanego nakazowo-rozdzielczego systemu gospodarki socjalistycznej cały przemysł, w ścisłym słowa znaczeniu, został stopniowo znacjonalizowany, głównie upaństwowiony. W rękach prywatnych władze PRL pozostawiły jedynie rzemiosło przemysłowe, reprezentowane przez najmniejsze jednostki produkcyjne, zatrudniające z reguły poniżej 5 pracowników. Jednak rozwój tego rzemiosła był ściśle kontrolowany i hamowany przez władze przy użyciu środków administracyjnych i dyskryminacyjnej polityki podatkowej. Obawiano się bowiem, że rozwój prywatnej działalności rzemieślniczej może przyczynić się do odrodzenia gospodarki kapitalistycznej.

Zielone światła dla rozwoju prywatnego rzemiosła przemysłowego zapalano w PRL kilkakrotnie w okresach wyraźnego pogorszenia się sytuacji zaopatrzeniowej ludności, 
a następnie ponownie je gaszono. W rezultacie przez pierwsze trzy dekady PRL liczba pracujących w tym rzemiośle utrzymywała się na podobnym poziomie. W $1946 \mathrm{r}$. wynosiła ona 227 tys. osób (w 1938/39 - 1147 tys.), a w 1975 r. - 239 tys. Tak więc w latach 1946-1975 udział prywatnego rzemiosła przemysłowego w ogólnej liczbie pracujących w całej działalności przemysłowej zmniejszył się z 15,6\% do 4,3\%, tj. 4,5-krotnie.

Dopiero w wyniku narastania wielkiego kryzysu ekonomicznego w Polsce, który wybuchł gwałtownie w 1980 r., władze PRL zdecydowały się zapalić na dłuższy czas zielone światło dla rozwoju rzemiosła prywatnego, a nawet wyraziły zgodę na zakładanie zagranicznych przedsiębiorstw drobnej wytwórczości, zwanych polonijnymi, ponieważ ich właścicielami byli głównie obywatele państw obcych polskiego pochodzenia. W rezultacie w końcu 1988 r. w prywatnym rzemiośle przemysłowym Polski zatrudnionych było 601 tys. pracowników, tj. dwa i pół razy więcej niż w 1975 r. Ponadto 69 tys. osób pracowało w zagranicznych przedsiębiorstwach drobnej wytwórczości. W końcu ostatniego pełnego roku okresu PRL sektor prywatny skupiał 12,7\% wszystkich pracujących w działalności przemysłowej kraju, tj. trzy razy więcej niż w 1975 r. Znaczny przyrost pracujących w prywatnym rzemiośle miał miejsce również w dwóch pierwszych latach transformacji (1989-1990). Jednak w wyniku dużego wzrostu podatków w 1990 r. liczba zakładów zarejestrowanych oraz zatrudnienie w rzemiośle zaczęły maleć i dotychczas nie osiągnęły poziomu z 1990 r. Duża cześć tych zakładów zrezygnowała z rejestracji i zasiliła "szarą strefę". Należy dodać, że od października 1990 r. te najmniejsze jednostki produkcyjne, liczące $z$ reguły poniżej 6 osób, określane są przez GUS podmiotami przemysłowymi prowadzonymi przez osoby fizyczne, a termin rzemiosło wyszedł z użycia.

Proces prywatyzacji działalności przemysłowej w Polsce na dużą skalę, obejmujący nie tylko drobną wytwórczość, lecz również średnie i wielkie fabryki rozpoczął się dopiero w drugiej połowie 1989 r., po dojściu do władzy dotychczasowej antykomunistycznej opozycji. Odbywał się on w niekorzystnych warunkach pogłębionej recesji w przemyśle zapoczątkowanej w 1981 r. i do końca okresu PRL nie przezwyciężonej, ogromnego zadłużenia kraju, galopującej inflacji i utraty dotychczasowych rynków zaopatrzenia i zbytu w wyniku likwidacji Rady Wzajemnej Pomocy Gospodarczej (RWPG).

W końcu 1988 r. liczba pracujących w przemyśle i w rzemiośle przemysłowym na obszarze Polski wynosiła 4,8 mln osób, tj. kształtowała się na poziomie o ok. 15\% niższym niż w 1980 r. Jak wynika z tabeli 1, w 1989 r. nastąpił niewielki (o 3,6\%) wzrost liczby pracujących. Jednak odtąd, aż do 1993 r. wystąpił gwałtowny spadek liczby pracujących, który

w ciagu 4 lat objął 1268 tys. osób, tj. ponad 25\%. Silna tendencja spadkowa liczby pracujących w przemyśle była cechą charakterystyczną wszystkich województw. Jednak w całym kraju i w większości województw od 1993 r. do 1997 r. pojawiła się tendencja umiarkowanego wzrostu liczby pracujących w przemyśle. Wyjątek stanowi 5 województw: katowickie, wałbrzyskie, legnickie, łódzkie i radomskie, w których przez cały okres transformacji (1989-1998) liczba pracujących w przemyśle z roku na rok malała. Należy podkreślić, że

w kilku wielkich ośrodkach przemysłowych, takich jak Łódź, Radom i Wałbrzych oraz w wielu mniejszych liczba pracujących w działalności przemysłowej w 1998 r. była 2-3 razy niższa niż w $1989 \mathrm{r}$.

Wydaje się, że znaczny wpływ na pojawienie się w latach 1994-1997 tendencji wzrostu liczby pracujących w przemyśle wywarło zaliczenie doń niektórych rodzajów działalności, które przed 1994 r. wchodziły w skład innych działów gospodarki (np. działalność 
wydawnicza i zaopatrzenie $\mathrm{w}$ wodę). Jednak w ostatnim roku badanego okresu (1997-1998) można obserwować znów spadek liczby pracujących w przemyśle całego kraju i większości województw. Trudno będzie dokładniej zbadać, czy to jest tendencja trwalsza, ponieważ od 1.01.1999 r. funkcjonują nowe województwa w liczbie 16. Jest mało prawdopodobne, żeby GUS agregował dalej dane z tego zakresu w układzie starych 49 województw. Warto zaznaczyć, że ponad 70\% krajowego spadku pracujących w działalności przemysłowej skupiało się w tym roku na obszarze 4 województw: katowickiego $55 \%$, łódzkiego $-8,2 \%$, opolskiego $-6 \%$ i wałbrzyskiego $-5 \%$, natomiast w 14 województwach, głównie słabo uprzemysłowionych we wschodniej i północnej części kraju, liczba pracujących w działalności przemysłowej utrzymywała się w 1998 r. na nieco wyższym niż w 1997 r. poziomie lub takim samym.

Spośród 3 sekcji działalności zaliczanych przez GUS do działu przemysłu największy spadek bezwzględnej liczby pracujących wykazywała w latach 1997-1998 działalność produkcyjna - z 3177 tys. do 3100 tys., następnie górnictwo i kopalnictwo - z 326 tys. do 297 tys., a najmniejszy zaopatrzenie w energię elektryczną i wodę - z 258 tys. do 253 tys.

Jak wynika z tabeli 1, w całej badanej dekadzie (1989-1998) liczba pracujących w działalności przemysłowej zmniejszyła się o 1322 tys., tj. o 26,5\%, w tym najwięcej, bo o 2850 tys., czyli o $33 \%$ w najwyżej uprzemysłowionym woj. katowickim, o 107 tys., tj. o $28 \%$ w woj. warszawskim i o 94 tys., tj. o $45 \%$ w łódzkim. W przypadku województw warszawskiego i łódzkiego ten duży spadek spowodowany był w znacznym stopniu bankructwem i likwidacją licznych wielkich zakładów, a w województwie katowickim zmniejszeniem produkcji i zatrudnienia w dominującym tu przemyśle górniczo-hutniczym. Przemysł ten procesem prywatyzacji objęty został z opóźnieniem, dopiero w ostatnich dwóch latach omawianej dekady. Należy dodać, że o 59 tys. osób, tj. o 44\% spadła liczba pracujących w tej dekadzie w woj. wałbrzyskim w wyniku niemal całkowitej likwidacji górnictwa węglowego na tym obszarze. W pozostałych województwach spadek liczby pracujących

w działalności przemysłowej w liczbach bezwzględnych był mniejszy, ale procentowo w niektórych z nich również wysoki, przekraczając 30\%. Na podkreślenie zasługuje fakt, że tylko

w dwóch słabiej uprzemysłowionych województwach: leszczyńskim i pilskim liczba pracujących w działalności przemysłowej była w 1998 r. o kilka procent wyższa niż w 1989 r.

Bankructwo i likwidacja licznych państwowych fabryk, zwłaszcza wielkich, w procesie rozpoczętej w 1989 roku transformacji wywierały określony wpływ na dynamikę i efekty prywatyzacji działalności przemysłowej. Proces prywatyzacji przemysłu przebiegał w Polsce

w bardzo szybkim tempie. O ile w końcu 1989 r. sektor prywatny skupiał tylko 15\% wszystkich pracujących w przemyśle i rzemiośle (w 1988 r.- 12,7\%), to w 1998 r. już $70,1 \%$.

Poszczególne sekcje działalności przemysłowej w Polsce wykazują wielkie różnice z punktu widzenia dynamiki i stopnia zaawansowania procesu prywatyzacji. Bardzo wysoki poziom prywatyzacji wykazuje tylko sekcja 2, tzw. działalność produkcyjna, obejmująca przemysł przetwórczy. Według danych GUS z dnia 30 IX 1998 roku zakłady przemysłowe zaliczone do tej sekcji zatrudniały ogółem 3100 tys. pracowników, w tym 2525,5 tys. w sektorze prywatnym. Oznacza to, że zakłady prywatne skupiały $81,5 \%$ wszystkich pracujących w tej sekcji, a sektor publiczny tylko $18,5 \%$. 
Tymczasem w sekcji 1, tj. w górnictwie i kopalnictwie, zatrudniającym w całym kraju 297 tys. osób, sektor prywatny skupiał w dniu 30 IX 1998 r. tylko 205 tys. pracowników, tj. 6,9\% wszystkich pracujących. Jeszcze niższy stopień prywatyzacji osiągnęła w Polsce sekcja 3, tj. zaopatrzenie w energię elektryczną, gaz i wodę. Na ogólną liczbę pracujących w tej sekcji w skali krajowej (252,7 tys. osób), w sektorze prywatnym pracowało zaledwie 14,4 tys. osób, tj. 5,7\%.

Na podstawie przytoczonych danych można więc twierdzić, że mimo upływu 10 lat od rozpoczęcia w Polsce transformacji proces prywatyzacji górnictwa i kopalnictwa oraz zaopatrzenia w energię elektryczną, gaz i wodę znajduje się nadal w stadium początkowym. Według opracowanej przez władze państwowe strategii rozwoju kraju do $2010 \mathrm{r}$. proces prywatyzacji zakładów należących do obu tych sekcji wymagać będzie dłuższego czasu

z powodu trudności znalezienia bogatych inwestorów. Górnictwo i kopalnictwo koncentruje się głównie w woj. katowickim oraz kilku innych województwach (jeleniogórskie, konińskie, legnickie, piotrkowskie, tarnobrzeskie i wałbrzyskie). Zaopatrzenie w energię elektryczną, gaz i wodę wykazuje natomiast znaczne rozproszenie w kraju.

Tabela 1 
Jeśli chodzi o sektor publiczny, to jego rola w strukturze własnościowej działalności przemysłowej na obszarze Polski w mijającej dekadzie transformacji bardzo poważnie zmalała. Pod koniec 1998 r. (30 IX) sektor ten skupiał tylko 1086 tys., tj. 29,1\% pracowników całego przemysłu kraju (w 1989 r. - 85\%), ale w górnictwie i kopalnictwie nadal $93,1 \%$,

a w zaopatrzeniu w energię elektryczną, gaz i wodę 94,3\%. W obu tych sekcjach przemysłu na początku transformacji w 1989 r. sektor publiczny miał absolutny (100\%) monopol.

W 1990 roku reaktywowany został w Polsce sektor komunalny w przemyśle, zlikwidowany w 1949 r. przez władze PRL razem z samorządami. Odgrywa on jednak niewielką rolę w przemyśle kraju. W końcu września 1998 r. skupiał on tylko 93 tys. pracowników, tj. zaledwie 2,6\% wszystkich pracujących w przemyśle. Znaczącą rolę odgrywa sektor komunalny tylko w zaopatrzeniu w energię elektryczna, gaz i wodę, skupiając 34,5\% pracujących w tej działalności.

Osiagnięty w ciągu badanej dekady poziom prywatyzacji działalności przemysłowej w Polsce jest przestrzennie dość silnie zróżnicowany. Wykazują to dane zamieszone w tabeli 2, a jeszcze lepiej opracowane na ich podstawie mapy, które pozwalają śledzić wizualnie coroczne zmiany w tym zakresie od początku transformacji.

Przestrzenne zróżnicowanie poziomu prywatyzacji działalności przemysłowej spowodowane zostało przez różnorodne czynniki. Znaczny wpływ wywarł m.in. stopień prywatyzacji wytwórczości w 1989 r. - wyjściowym roku transformacji oraz ukształtowana w okresie PRL struktura gałęziowa przemysłu konkretnego województwa, zwłaszcza udział w nim górnictwa, struktura wielkości zakładów i rola w przemyśle województwa sektora spółdzielczego, który po zmianach organizacyjnych przeprowadzonych w spółdzielczości w 1990 r. zaliczono całkowicie do sektora prywatnego. Jednak, jak wynika z tabeli 2, wielkie różnice w stopniu prywatyzacji działalności przemysłowej poszczególnych województw ulegały stopniowej niwelacji. W 1998 r. były one kilkakrotnie mniejsze niż przed 10 laty. O ile w 1988 r. dystans dzielący województwo $\mathrm{z}$ najsłabiej sprywatyzowanym przemysłem od województw o najwyższym stopniu prywatyzacji kształtował się jak 1:5, to w 1998 r. już tylko jak 1:2.

Analiza statystyczna danych zawartych w tabeli 2 oraz analiza wizualna załączonych map wykazuje, że w okresie transformacji zapoczątkowanej w 1989 r. najwyższą dynamiką procesu prywatyzacji, a w rezultacie również najwyższym stopniem jej zaawansowania w końcowych latach badanej dekady wyróżniały się z reguły (z kilkoma wyjątkami) woje- 
wództwa, które pod koniec PRL zaliczano do grup najsłabiej lub słabo uprzemysłowionych. W województwach tych dominowały przed 1989 r. zakłady małe, zatrudniające do 100 osób oraz średnie, zatrudniające 101-500 osób. Zakłady państwowe tej skali wielkości łatwiej poddawały się prywatyzacji niż zakłady giganty.

Z punktu widzenia stopnia zaawansowania prywatyzacji można wyróżnić w końcu września 1998 r. 5 grup województw:

- województwa o bardzo wysokim stopniu prywatyzacji działalności przemysłowej, powyżej $80 \%$ pracujących w tym dziale gospodarki,

- województwa o wysokim stopniu prywatyzacji wynoszącym $71-80 \%$ ogółu pracujących, czyli powyżej średniej krajowej, wynoszącej 70,1\%,

- województwa o nieco mniej niż średnim poziomie prywatyzacji, wynoszącym $61-70 \%$ pracujących,

- województwa o niskim stopniu prywatyzacji, wynoszącym 51-60\% pracujących,

- województwa o bardzo niskim w polskich warunkach stopniu prywatyzacji, kształtującym się na poziomie poniżej 50\% ogółu pracujących w działalności przemysłowej.

Grupę najliczniejszą, o bardzo wysokich wskaźnikach prywatyzacji działalności przemysłowej, tworzą 22 województwa: leszczyńskie $-88,7 \%$, pilskie $-87,8 \%$, słupskie $87,4 \%$, kaliskie $-85,7 \%$, ciechanowskie $-85,3 \%$, elbląskie $-85,1 \%$, olsztyńskie $-85,1 \%$, skierniewickie $-84,8 \%$, suwalskie $-84,7 \%$, poznańskie $-84,7 \%$, koszalińskie $-84,2 \%$, gorzowskie $-83,9 \%$, wrocławskie $-83,3 \%$, sieradzkie $-81,6 \%$, ostrołęckie $-82,9 \%$, łomżyńskie $-82,6 \%$, przemyskie $-81,9 \%$, włocławskie $-81,8 \%$, nowosądeckie $-81,7 \%$, siedleckie $-81,6 \%$, łódzkie $-81,7 \%$ i bialskopodlaskie $-80,9 \%$.

W skład tej grupy wchodzą w większości słabo i bardzo słabo uprzemysłowione przed 1989 r. województwa położone we wschodniej i północnej części kraju. W strukturze gałęziowej wielką rolę odgrywały w nich przemysły spożywczy i drzewny, w których proces prywatyzacji przebiegał po 1989 r. najszybciej. Procesowi szybkiej prywatyzacji sprzyjała ponadto wspomniana struktura wielkościowa zakładów, z przewagą zakładów małych i średnich. Należy podkreślić, że w grupie tej znalazły się również trzy województwa wysoko przed 1989 r. uprzemysłowione, tj. łódzkie, poznańskie i wrocławskie, z przewaga prze-mysłu wielkiego. Jednak liczne wielkie fabryki, zwłaszcza w Łodzi, zbankrutowały i zostały zlikwidowane, a ich miejsce zajęły prywatne zakłady drobne i średnie.

Znacznie mniejszą grupę tworzą województwa o nieco słabszych wskaźnikach prywatyzacji przemysłu, wynoszących 71-80\% pracujących w przemyśle, lecz kształtujących się powyżej średniego wskaźnika krajowego, wynoszącego 70,1\%. Do grupy tej zaliczają się następujące województwa: częstochowskie - 80,0\%, toruńskie - 78,4\%, zielonogórskie - 78,2\%, zamojskie $-78,0 \%$, warszawskie $-77,8 \%$, bydgoskie $-74,8 \%$, wałbrzyskie $-74,7 \%$, szczecińskie $74,1 \%$, chełmskie $-72,7 \%$, tarnowskie $-72,3 \%$, krośnieńskie $-71,8 \%$ i białostockie $-71,6 \%$.

W skład tej grupy wchodzą głównie województwa średnio uprzemysłowione przed 1989 r. Znajdują się w niej również dwa województwa bardzo słabo uprzemysłowione, tj. chełmskie i zamojskie oraz jedno bardzo wysoko uprzemysłowione - woj. wałbrzyskie. W tym ostatnim województwie odgrywające przedtem dużą rolę górnictwo węgla kamiennego zostało w okresie transformacji niemal całkowicie zlikwidowane, a na jego miejsce zlokalizowano sporo drobnych i średniej wielkości zakładów prywatnych.

Grupę o średnio sprywatyzowanej w skali kraju działalności przemysłowej, ze wskaźnikami prywatyzacji 61-70\% tworzyło w 1989 r. 9 województw: kieleckie - 68,5\%, gdańskie $-67,7 \%$, rzeszowskie $-66,6 \%$, krakowskie $-66,2 \%$, płockie $-66,5 \%$, opolskie $65,4 \%$, konińskie $-64,7 \%$, radomskie $-62,9 \%$ i lubelskie $-62,5 \%$. 
Większość województw tej grupy zaliczało się w okresie PRL-u do średnio uprzemysłowionych, w tym cztery (gdańskie, kieleckie, krakowskie i opolskie) do wysoko uprzemysłowionych. W przemyśle wszystkich tych województw dominowały wielkie fabryki, których proces prywatyzacji w całym kraju postępuje dużo wolniej niż w zakładach mniejszych. W woj. konińskim proces prywatyzacji utrudniony jest dodatkowo przez odgrywającą w nim dużą rolę działalność górniczą, która dotychczas nie wzbudza większego zainteresowania inwestorów prywatnych.

Do grupy o stosunkowo słabo zaawansowanym stopniu prywatyzacji (51-60\%) zaliczają się tylko 4 województwa: piotrkowskie $-60,0 \%$, bielskie $-59,6 \%$, jeleniogórskie $-58,8 \%$ i tarnobrzeskie $-51,1 \%$. Województwa bielskie i jeleniogórskie tradycyjnie zaliczane były do najwyżej uprzemysłowionych na ziemiach polskich, przy czym w okresie PRL na dużą skalę rozbudowano w nich przemysł wielki, zaś województwa piotrkowskie i tarnobrzeskie swój awans po II wojnie światowej do grupy regionów wysoko uprzemysłowionych zawdzięczają w dużym stopniu rozwojowi górnictwa węgla brunatnego i siarki. Górnictwo węgla brunatnego odegrało też dużą rolę w rozwoju przemysłowym woj. jeleniogórskiego. Wielkie kopalnie i ogromne zakłady opierające swą produkcję na wydobywanych surowcach opóźniają w znacznym stopniu proces prywatyzacji przemysłu w tych województwach.

Tabela 2 
Ostatnią grupę, o najniższych wskaźnikach prywatyzacji przemysłu w Polsce (poniżej $50 \%$ ), stanowią tylko dwa województwa: legnickie $-49,1 \%$ i katowickie $-49,1 \%$. Obszar woj. katowickiego dzięki bogatym zasobom węgla kamiennego od połowy XIX w. był naj-wyżej uprzemysłowionym regionem na ziemiach polskich, zaś woj. legnickie swój awans do regionów wysoko uprzemysłowionych zawdzięcza głównie odkryciu po 1945 r. zasobnych złóż miedzi i budowie na ich bazie metalurgii tego metalu. Jak wynika z tabeli 2, obydwa województwa od początku transformacji zajmują ostatnie miejsca w kraju z punktu widzenia stopnia zaawansowania prywatyzacji działalności przemysłowej, z powodu dominacji

w nich przemysłu górniczo-hutniczego. Rozwiązanie problemu prywatyzacji tego bardzo kapitałochłonnego przemysłu nastręcza największych trudności nie tylko w Polsce. Należy 
jednak podkreślić, że i w tym przemyśle w ostatnich latach 1997-1998 zanotowano znaczny postęp, prywatyzując wielki kombinat górniczo-hutniczy Polska Miedź S.A. w Lubinie

w woj. legnickim oraz kilka hut żelaza w woj. katowickim.

$\mathrm{Na}$ bardzo słabo i słabo uprzemysłowionych terenach wschodniej i północnej Polski możliwości efektywnej prywatyzacji przemysłu przetwórczego (sekcja 2 - działalność produkcyjna) są już na wyczerpaniu. W 10 województwach: bialskopodlaskim, chełmskim, elbląskim, koszalińskim, łomżyńskim, ostrołęckim, przemyskim, słupskim, suwalskim i zamojskim zatrudnienie w sektorze publicznym przemysłu przetwórczego jest już bardzo niskie, waha się od 1,3 tys. do 3 tys. osób. Nieznaczne możliwości prywatyzacji w wymienionych województwach pozbawionych górnictwa występują również w sekcji 3 przemysłu, tj. w zaopatrzeniu w energię elektryczna, gaz i wodę. Wydaje się, że pełna prywatyzacja $(100 \%)$ działalności przemysłowej nie byłaby celowa i uzasadniona. Niektóre jej rodzaje powinny nadal pozostać w sektorze publicznym (państwowym lub samorządowym). Przykłady innych krajów europejskich i pozaeuropejskich z gospodarką rynkową świadczą, że nigdzie działalność przemysłowa nie jest sprywatyzowana całkowicie.

W Polsce największe możliwości dalszej prywatyzacji występują w 15 województwach przeważnie wysoko w okresie PRL uprzemysłowionych, które zaliczono w niniejszym opracowaniu do grup 3-5.

\section{NAJWIĘKSZE PRZEDSIĘBIORSTWA PRZEMYSŁOWE WOJEWÓDZTW SPRYWATYZOWANE W LATACH 1989-1998}

Jakkolwiek w toku dotychczasowej transformacji gospodarki narodowej (1988-1998) procesem prywatyzacji objęte zostały głównie małe i średnie zakłady przemysłowe, to jednak w większości województw sprywatyzowano również niektóre zakłady wielkie, zatrudniające powyżej 1 tys. pracowników. Jak wynika z opublikowanego w miesięczniku "Home and Market" z maja 1999 r. nr 5 raportu redakcji pt. 500 największych prywatnych firm produkcyjnych w $1998 r$. czynnych było w naszym kraju 145 wielkich prywatnych przedsiębiorstw przemysłowych zatrudniających powyżej 1000 pracowników, z tym że w niektórych z nich formalności prywatyzacyjne zostały zakończone dopiero w $1999 \mathrm{r}$. W Polsce tej skali wielkości przedsiębiorstw przemysłowych w $1997 \mathrm{r}$. było 423, w tym $338 \mathrm{w}$ przemyśle przetwórczym (Rocznik Statystyczny Przemysłu, GUS, 1998, s. 9). Tylko w 7 słabo uprzemysłowionych województwach: bialskopodlaskim, chełmskim, leszczyńskim, przemyskim, słupskim i zamojskim nie sprywatyzowano dotychczas ani jednego tej skali wielkości przedsiębiorstwa przemysłowego. W wymienionych województwach słabo uprzemysłowionych takich zakładów nie ma zresztą zbyt wiele.

Głównie na podstawie wymienionego raportu sporządzono zamieszczony w tabeli 3 wykaz wspomnianych wyżej 145 największych prywatnych przedsiębiorstw przemysłowych, zatrudniających wg stanu na dzień 31 XII 1998 r. powyżej 1000 pracowników.

$\mathrm{Z}$ analizy tego wykazu wynika, że $1 / 3 \mathrm{z}$ nich reprezentuje gałęzie i branże zaliczane do przemysłu wytwarzającego dobra konsumpcyjne, a 2/3 przedsiębiorstw gałęzie środków 
produkcji. Najwięcej wielkich prywatnych przedsiębiorstw należy do przemysłów: spożywczego (27), chemicznego (17), elektrotechnicznego i elektronicznego (14), środków transportu i maszynowego (po 10), włókienniczego (9), drzewnego i mineralnego (po 8), metalowego, odzieżowego, hutnictwa żelaza oraz hutnictwa metali nieżelaznych (po 5) oraz innych gałęzi po 2-4 przedsiębiorstwa.

Tabela 3. Największe przedsiębiorstwa przemysłowe sprywatyzowane w latach 1989-1998 według województw

\begin{tabular}{|c|c|c|c|c|}
\hline Lp. & Nazwa przedsiębiorstwa & Województwo & $\begin{array}{c}\text { Gałąź } \\
\text { przemysłu }\end{array}$ & $\begin{array}{c}\text { Liczba } \\
\text { zatrud. } \\
31.12 .98\end{array}$ \\
\hline 1. & Daewoo FSO Motor sp. z o.o. Warszawa & warszawskie & śr. transp. & 12877 \\
\hline 2. & Thomson Polkolor S.A. Piaseczno & “" & eletron. & 5498 \\
\hline 3. & Inco Veritas sp. z o.o. Warszawa & “ & chemiczny & 3655 \\
\hline 4. & Unilever Polska S.A. Warszawa & “" & “ & 3500 \\
\hline 5. & E. Wedel S.A. Warszawa & " & “ & 3129 \\
\hline 6. & Huta Luccini Warszawa & “" & hutniczy & 2849 \\
\hline 7. & Bumar Waryński S.A. Warszawa & “" & maszynowy & 1977 \\
\hline 8. & Furnel S.A. Warszawa & “" & drzewny & 2346 \\
\hline 9. & Agora S.A. Warszawa & " & poligraficzny & 2426 \\
\hline 10. & Farm Food S.A. Warszawa & “" & spożywczy & 1041 \\
\hline 11. & “ZREW” Z-dy Remont. Energet. S.A. Warszawa & “ & maszynowy & 1107 \\
\hline 12. & Procter and Gamble Operations S.A. Warszawa & “" & chemiczny & 1051 \\
\hline 13. & Stolarka S.A. Wołomin & “ & drzewny & 1225 \\
\hline 14. & Daewoo Electronics Sp. z o.o. Pruszków & “" & elektron. & 1100 \\
\hline 15. & Fabryka dywanów “ANGELLA” S.A. Białystok & białostockie & włókienniczy & 1100 \\
\hline 16. & Z-dy Metalurgiczne Kąty S.A. & bielskie & hutniczo-met. & 1347 \\
\hline 17. & Fiat Auto Poland S.A. Bielsko-Biała & bielskie & śr. transp. & 10789 \\
\hline 18. & DWORY Oświęcim S.A. & “ & chemiczny & 3713 \\
\hline 19. & Texo Poland S.A. Bielsko-Biała & “ & metalowy & 1502 \\
\hline 20. & FRANTSSHACA Świecie S.A. & bydgoskie & papierniczy & 3130 \\
\hline 21. & Huta Szkła Gosp. "Irena” S.A. Inowrocław & “ & szklarski & 1236 \\
\hline 22. & $\begin{array}{l}\text { LUCENT TECHNOLOGIES POLAND S.A. } \\
\text { Bydgoszcz }\end{array}$ & "“ & elektron. & 1267 \\
\hline 23. & ATAT-Telfa S.A. Bydgoszcz & “" & “ & 1159 \\
\hline 24. & KRUSZWICA S.A. Kruszwica & “" & spożywczy & 1215 \\
\hline 25. & Jutrzenka S.A. Bydgoszcz & “ & “ & 1149 \\
\hline 26. & Lever Polska S.A. Bydgoszcz & “" & chemiczny & 1057 \\
\hline 27. & Soda Mątwy S.A. Inowrocław & “ & “ & 1727 \\
\hline 28. & Janiko Soda S.A. Janikowo & “ & \begin{tabular}{|l} 
“ \\
\end{tabular} & 1487 \\
\hline 29. & Chojnickie Fabryki Mebli S.A. & “" & drzewny & 1051 \\
\hline 30. & Hortex Holding S.A. Płońsk & ciechanowskie & spożywczy & 5478 \\
\hline 31. & Komb. Cement.-Wapien. "Warta" S.A. Działoszyn & częstochowskie & mat. bud. & 1619 \\
\hline 32. & Lentax S.A. Lubliniec & “ & chemiczny & 1180 \\
\hline 33. & Stolbud S.A. Włoszczowa & “ & drzewny & 1350 \\
\hline 34. & ABB Zamech Ltd. Elbląg & elbląskie & maszyn. & 3150 \\
\hline 35. & Inernational Paper-Kwidzyn Polska S.A. & “" & papier. & 2223 \\
\hline 36. & “"Elbrewery” Company Ltd. Elbląg & “ & spożywczy & 1984 \\
\hline 37. & Stocznia Gdyńska S.A. Gdynia & gdańskie & śr. transp. & 8204 \\
\hline
\end{tabular}




\begin{tabular}{|c|c|c|c|c|}
\hline 38. & Stocznia Północna Gdańsk S.A. & " & “ & 1412 \\
\hline 39. & Lubiana S.A. Łubiana & “" & “" & 1455 \\
\hline 40. & Silon S.A. Gorzów Wlkp. & gorzowskie & chemiczny & 2912 \\
\hline 41. & Kostrzyńskie Z-dy Papiern. S.A. & “ & papier. & 1103 \\
\hline 42. & “Jelfa” S.A. Jelenia Góra & jeleniogórskie & chemiczny & 1242 \\
\hline 43. & WSM Krotoszyn & kaliskie & śr. transp. & 1493 \\
\hline 44. & "Winiary" S.A. Kalisz & “ & spożywczy & 1358 \\
\hline 45. & WISTR S.A. Kalisz & “ & włókien. & 1325 \\
\hline 46. & ZUGIL Wieluń & “" & maszynowy & 1472 \\
\hline 47. & ZAP S.A. Ostrów Wlkp. & “" & precyz. & 1188 \\
\hline 48. & Haft S.A. Kalisz & “ & włókien. & 1069 \\
\hline 49. & Z-dy Górn.-Hutn. Bolesław Bakowno & katowicki & hutn. & 3412 \\
\hline 50. & Emalia Olkusz S.A. & “6 & metalowy & 3172 \\
\hline 51. & Huta Batory S.A. Chorzów & “" & hutn. & 3832 \\
\hline 52. & Z-dy Odzieżowe "Bytom" S.A. & “" & odzież. & 3032 \\
\hline 53. & Fabryka Kotłów RAFAKO S.A. Racibórz & “" & maszyn. & 2317 \\
\hline 54. & Walcownia Metali Dziedzice & “" & hutn. m.n. & 1374 \\
\hline 55. & Odlewnia Żeliwa “Zawiercie” S.A. & “" & metalowy & 1571 \\
\hline 56. & Z-dy Elektrod Węglowych Racibórz & “" & elektrotechn. & 1100 \\
\hline 57. & "Contact-Powen" S.A. Zabrze & “" & maszyn. & 1120 \\
\hline 58. & Huta Buczka S.A. Sosnowiec & “ & hutn. & 1220 \\
\hline 59. & Zakłady Mechaniczne “Zamet” S.A. & “" & maszyn. & 1081 \\
\hline 60. & Huta Ferrum S.A. Katowice & “" & hutn. & 1030 \\
\hline 61. & Huta Zygmunt S.A. Bytom & “" & “ & 1200 \\
\hline 62. & Śląskpol. S.A. Katowice & “" & & \\
\hline 63. & Zabrz. Z-dy Napr. Przem. Węgl. S.A. Zabrze & “" & maszyn. & 1009 \\
\hline 64. & Ryfama S.A. Rybnik & “" & maszyn. & 1000 \\
\hline 65. & Kop. Piasku Podsadz. S.A. Szczakowa & “ & mat. bud. & 1051 \\
\hline 66. & PROMUS Sp. z o o & “" & metalowy & 1058 \\
\hline 67. & Zakłady Starachowickie "Star” S.A. & kielecki & śr. transp. & 2587 \\
\hline 68. & Zakład Walcowni "Huty Ostrowiec” S.A. & “ & hutn. & 1460 \\
\hline 69. & Dawid S. Smith S.A. Kielce & “" & papier. & 1097 \\
\hline 70. & Odlewnie Polskie S.A. Kielce & “ & metal. & 1040 \\
\hline 71. & Constar S.A. Starachowice & “" & spożyw. & 1059 \\
\hline 72. & Huta Aluminium S.A. Konin & konińskie & hutn. m.n. & 1344 \\
\hline 73. & Z-dy Mięsne w Kole S.A. & \begin{tabular}{|c|}
$،$ \\
\end{tabular} & spożyw. & 1580 \\
\hline 74. & Korund S.A. Koło & “" & miner. & 1317 \\
\hline 75. & Fugo S.A. Konin & “" & hut. m.n. & 1397 \\
\hline 76. & ELDA S.A. Szczecinek & koszaliński & elektron. & 1136 \\
\hline 77. & Kosz. Przeds. Przem. Drzew. S.A. & “ & drzewny & 1137 \\
\hline 78. & Vistula S.A. Kraków & krakowski & odzież. & 2693 \\
\hline 79. & CAN PACK S.A. Kraków & “ & metalowy & 2326 \\
\hline 80. & Krakowska Fabryka Kabli S.A. & “ & elektrotechn. & 1818 \\
\hline 81. & ZPC Wawel S.A. Kraków & “" & spożywczy & 1693 \\
\hline 82. & PRP "Bemer-HTS” S.A. Kraków & “ & maszyn. & 1156 \\
\hline 83. & Przeds. Mater. Ogniotrw. S.A. Kraków & “ & mat. bud. & 1030 \\
\hline 84. & Bahlsen Koncentr. Spożyw. S.A. Skawina & “ & spożywczy & 1077 \\
\hline 85. & Krośnieńskie Huty Szkła Krosno S.A. & krośnieński & szklarski & 4660 \\
\hline
\end{tabular}




\begin{tabular}{|c|c|c|c|c|}
\hline 86. & “Autosan" S.A. Sanok & “ & śr. transp. & 2126 \\
\hline 87. & "Stomil” Sanok S.A. & “ & chemiczny & 1860 \\
\hline 88. & KGHM Polska Miedź S.A. Lubin & legnickie & hut. m.n. & 19935 \\
\hline 89. & Daewoo Motor sp. z o.o. Lublin & lubelskie & śr. transp. & 6340 \\
\hline 90. & Lubelska WSK PZL Świdnik S.A. & “ & śr. transp. & 4387 \\
\hline 91. & Protector S.A. Lublin & “ & spożywczy & 1120 \\
\hline 92. & PEPEES S.A. Łomża & łomżyński & spożywczy & 1140 \\
\hline 93. & Wólczanka S.A. Łódź & łódzkie & odzieżowy & 3255 \\
\hline 94. & Próchnik S.A. Łódź & “6 & odzieżowy & 1522 \\
\hline 95. & WI-MA S.A. Łódź & “ & włókien. & 1140 \\
\hline 96. & Poligraph Nowy Sącz & nowosądecki & elektron. & 1162 \\
\hline 97. & Stomil Olsztyn S.A. & olsztyńskie & chemiczny & 4300 \\
\hline 98. & MM International S.A. Olsztyn & “ & drzewny & 3791 \\
\hline 99. & Z-dy Mięsne Ostróda Morliny S.A. & “ & spożywczy & 1863 \\
\hline 100. & Indykpol S.A. Olsztyn & $\begin{array}{r}\text { “ } \\
\end{array}$ & “ & 1518 \\
\hline 101. & Huta Małapanew Ozimek & opolskie & hutniczy & 2717 \\
\hline 102 & Oplskie F-ki Mebli S.A. Opole & “ & drzewny & 1914 \\
\hline 103 & Fabryka Kotłów "Rafako" S.A. Racibórz & “ & maszynowy & 2317 \\
\hline 104 & Frotex S.A. Prudnik & “" & włókien. & 1463 \\
\hline 105 & Górażdże S.A. & “ & mat. bud. & 1210 \\
\hline 106 & Kostrzyn Paper "Intercell” S.A. Ostrołęka & ostrołęcki & papier & 2308 \\
\hline 107 & Z.M. Ostrołęka S.A. Ostrołęka & “ & spożywczy & 1255 \\
\hline 108 & Fabryka Mebli "Forte" S.A. Ostr. Maz. & “ & drzewny & 2390 \\
\hline 109 & PHILIPS LIGHTING S.A. Piła & pilskie & elektron. & 3778 \\
\hline 110. & AMICA WRONKI & “ & metalowy & 2119 \\
\hline 111. & Winkowski sp. z o.o. (z-dy graficzne) & “ & poligraf. & 1050 \\
\hline 112. & Chodzież S.A. Chodzież & “" & mineralny & 1049 \\
\hline 113. & Farmutil HS Śmiłowo & “ & spożywczy & 2272 \\
\hline 114. & “Star Foods” sp. z o.o. Tomaszów Maz. & piotrkowskie & “ & 1041 \\
\hline 115. & Pioma S.A. Piotrków Tryb. & “ & metalowy & 2928 \\
\hline 116. & Fameg S.A. Radomsko & “ & drzewny & 2646 \\
\hline 117. & Polfa Kutno S.A. & płockie & chemiczny & 1066 \\
\hline 118. & Bizon sp. z o.o. Płock & “ & maszynowy & 1260 \\
\hline 119. & Swarzędzkie Fabryki Mebli S.A. & poznańskie & drzewny & 2413 \\
\hline 120. & Volkswagen Poznań & “ & śr. transp. & 2261 \\
\hline 121. & Goplana S.A. Poznań & “" & spożywczy & 1373 \\
\hline 122. & Tonsil S.A. Września & “ & elektrotechn. & 1495 \\
\hline 123. & Fabr. Kosmet. "Pollena-Lechia” Poznań & “" & chemiczny & 1604 \\
\hline 124. & Glaxo Welcome S.A. Poznań & “ & “ & 1396 \\
\hline 125. & Wielkop. F-ki Mebli S.A. Oborniki & “ & drzewny & 1440 \\
\hline 126. & Best food sp. z o.o. Polska Poznań & “ & spożywczy & 1035 \\
\hline 127. & Pozmeat S.A. Poznań & “ & “ & 1287 \\
\hline 128. & Z-dy Przem. Tytoniowego S.A. Radom & radomskie & “ & 1670 \\
\hline 129. & Gerlach S.A. Drzewica & “ & metalowy & 1041 \\
\hline 130. & Śrubex S.A. Łańcut & rzeszowskie & “ & 1181 \\
\hline 131. & Sokołów S.A. Sokołów Podlaski & siedleckie & spożywczy & 1709 \\
\hline 132. & Łukbud S.A. Siedlce & “ & skórzany & 1240 \\
\hline 133. & Mostostal Siedlce S.A. & " & metalowy & 1525 \\
\hline
\end{tabular}




\begin{tabular}{|c|c|c|c|c|}
\hline 134. & Drosed S.A. Siedlce & “" & spożywczy & 1345 \\
\hline 135. & LEAL Łochów S.A. & \begin{tabular}{|c|} 
“ \\
\end{tabular} & “ & 1828 \\
\hline 136. & Zwoltex S.A. Zduńska Wola & sieradzkie & włókien. & 2077 \\
\hline 137. & Rawa S.A. & skierniewickie & spożywczy & 1244 \\
\hline 138. & Agros-Łowicz S.A. & “ & " & 1033 \\
\hline 139. & Z-dy Lniarskie “Żyrardów” S.A. & “" & włókien. & 1187 \\
\hline 140. & Z-dy Mięsne Mazury S.A. Ełk & suwalskie & spożywcze & 1419 \\
\hline 141. & Stocznia Szczecińska S.A. & szczecińskie & śr. transp. & 8364 \\
\hline 142. & Załom S.A. Szczecin & “ & elektrotechn. & 1593 \\
\hline 143. & Pickington Sand Glass sp. z o.o. & tarnobrzeskie & szklarski & 1579 \\
\hline 144. & Z-dy Przem. Mięsnego S.A. Nisko & “6 & spożywczy & 1060 \\
\hline 145. & Firma Oponiarska Dębica S.A. & tarnowskie & chemiczny & 4901 \\
\hline 146. & Z-d Przetw. Hutn. S.A. Bochnia "Stal produkt" & “ & hutniczy & 2222 \\
\hline 147. & Okocim S.A. Brzesko & “" & spożywczy & 1055 \\
\hline 148. & Apator S.A. Toruń & toruńskie & elektrot. & 1031 \\
\hline 149. & TZMO S.A. Toruń & “6 & włókien. & 1364 \\
\hline 150. & Bielawa S.A. Bielawa & wałbrzyskie & “ & 2373 \\
\hline 151. & Pafal S.A. Świdnica & “ & elektrot. & 2074 \\
\hline 152. & Elmot S.A. Świdnica & “" & “ & 1108 \\
\hline 153. & Bieltexa S.A. Bielawa & “" & włókien. & 1700 \\
\hline 154. & Zakłady Azotowe S.A. Włocławek & włocławskie & chemiczny & 2913 \\
\hline 155. & ANWIL S.A. Włocławek & “ & “ & 2163 \\
\hline 156. & Jelcz S.A. & wrocławskie & śr. transp. & 2915 \\
\hline 157. & Polifarb Cieszyn-Wrocław & “ & chemiczny & 1821 \\
\hline 158. & ZCh Rokita S.A. Brzeg Dolny & “" & “ & 1874 \\
\hline 159. & Intermoda S.A. Wrocław & “" & odzieżowy & 1305 \\
\hline 160. & Hutmen S.A. Wrocław & “" & hutn. m.n. & 1408 \\
\hline 161. & Wrozamet S.A. Wrocław & “ & metalowy & 1782 \\
\hline 162. & Relpol S.A. Żary & zielonogórskie & maszyn. & 1040 \\
\hline 163. & Zastal S.A. Holding Zielona Góra & “6 & śr. transp. & 1231 \\
\hline
\end{tabular}

Źródła: Lista 500 w 1998 r., "Rzeczpospolita" z 6 V 1999 r.; 500 największych prywatnych firm produkcyjnych w 1998 r., "Home and Market" z maja 1999 r.

W układzie regionalnym najwięcej, bo 18 wielkich sprywatyzowanych przedsiębiorstw znajdowało się w 1998 r. na obszarze województwa warszawskiego. Jednak trzy spośród nich - wielozakładowe Furnel International Ltd. Sp. z o.o. Warszawa, Haste International Ltd.

sp. z o.o. oraz Unilever Polska S.A. Warszawa, utworzone na bazie średnich fabryk - maja w stolicy tylko siedziby swych zarządów, a ich wytwórnie rozmieszczone są poza jego granicami. Dwa dalsze wielkie przedsiębiorstwa wielozakładowe: Hortex S.A. Warszawa oraz Inco Veritas sp. z o.o. Warszawa mają w woj. warszawskim obok swych zarządów tylko pojedyncze średniej wielkości wytwórnie, a większość średniej wielkości zakładów funkcjonuje poza granicami tego województwa. Również największe przedsiębiorstwo warszawskie Daewoo FSO Motor sp. z o.o., które zatrudnia ogółem 12977 pracowników, w zarządzie i wielkim zakładzie macierzystym na Żeraniu oraz jego stołecznych filiach zatrudnia około połowy tej liczby, resztę w filiach zlokalizowanych w kilku innych województwach. 
Na drugim miejscu pod względem liczby sprywatyzowanych wielkich przedsiębiorstw przemysłowych znajdowało się w 1998 r. województwo katowickie, na którego obszarze funkcjonowało ich 17 , na trzecim bydgoskie - z 10 przedsiębiorstwami, na czwartym poznańskie - z 8, na piątym bielskie - z 7 przedsiębiorstwami. W pozostałych województwach liczba tej skali sprywatyzowanych przedsiębiorstw nie przekracza 5. Należy podkreślić, że na terytorium województwa katowickiego w Tychach znajduje się wielka fabryka, stanowiąca dużą część największego w Polsce sprywatyzowanego przedsiębiorstwa przemysłowego Fiat Auto Poland S.A. Bielsko-Biała, mającego swą siedzibę i kilka dużych oddziałów produkujących w województwie bielskim. Jednak kilkanaście sprywatyzowanych w województwie katowickim wielkich przedsiębiorstw stanowi niewielką część funkcjonujących tam gigantów przemysłowych. Spośród licznych wielkich kopalni na obszarze tego województwa do 1998 r. sprywatyzowano jedynie kopalnię piasku podsadzkowego w Szczakowej.

Obok stosunkowo niewielkiego odsetka sprywatyzowanych wielkich przedsiębiorstw przemysłowych w województwie katowickim rzuca się w oczy także znikoma liczba sprywatyzowanych tej skali wielkości zakładów w bardzo wysoko uprzemysłowionym województwie łódzkim, z dominującym przemysłem włókienniczym. Było ich tam pod koniec PRL-u ponad 70. Tymczasem na wspomnianej liście 500 znajdują się zaledwie dwa tej skali przedsiębiorstwa, przy czym reprezentują one tylko przemysł odzieżowy.

Należy dodać, że na "Liście 500" znajduje się ponad 200 dużych sprywatyzowanych przedsiębiorstw, w których zatrudnienie mieściło się w 1998 r. w graniach 500-1000 osób.

Największymi sprywatyzowanymi w Polsce w latach 1989-1998 przedsiębiorstwami przemysłowymi z punktu widzenia wartości produkcji sprzedanej i zatrudnienia były w 1998 r.: 1) Fiat Auto Poland z siedzibą w Bielsku Białej, 2) Deawoo FSO Motor sp. z o.o. z siedzibą w Warszawie i 3) KGHM Polska Miedź S.A. z siedzibą w Lubinie.

Należy podkreślić, że wszystkie wielkie fabryki w Polsce zatrudniające powyżej 1 tys. pracowników powstały przed 1989 r. Zakłady przemysłowe tej skali wielkości zbudowane od fundamentów, czyli na "surowym korzeniu" lub na "zielonej łące” można policzyć na palcach.

\section{ROLA KAPITAŁU ZAGRANICZNEGO W RESTRUKTURYZACJI WŁASNOŚCIOWEJ PRZEMYSŁU POLSKIEGO}

W procesie prywatyzacji przemysłu w Polsce dużą rolę odegrali inwestorzy zagraniczni. Według danych GUS-u (Pracujacy w gospodarce narodowej w 1998, GUS, Warszawa 1999, s. 5) w dniu 30 IX 1998 r. w zagranicznych przedsiębiorstwach przemysłowych na terenie Polski pracowało 264 tys. osób. Ponadto 528 tys. osób pracowało w zakładach przemysłowych stanowiących własność mieszaną, czyli z udziałem kapitału zagranicznego. Łącznie w przedsiębiorstwach będących własnością inwestorów zagranicznych i własnością mieszaną zatrudnionych było 792 tys. pracowników, tj. 30,9\% wszystkich pracujących w sektorze prywatnym działalności przemysłowej i 21,7\% w całym przemyśle.

Dotychczas kapitał zagraniczny inwestował w Polsce niemal wyłącznie w przemysł przetwórczy, czyli w zakłady sekcji II, tj. tzw. działalność produkcyjną. W rezultacie sekcja ta skupiała w 1998 r. 99,5\% wszystkich pracujących w zakładach będących całkowicie 
własnością inwestorów zagranicznych (262 tys. osób) i 97,2\% (514 tys. osób) będących własnością mieszaną. W zagranicznych przedsiębiorstwach górniczych na obszarze Polski pracowało

w 1998 r. zaledwie 977 osób, a w jednostkach mieszanych 9088 osób. Jeszcze mniej zatrudniały nieliczne zagraniczne zakłady zajmujące się zaopatrzeniem w energię elektryczną, gaz

i wodę, bo tylko 312 pracowników, a jednostki o kapitale mieszanym 5727 pracowników.

Według danych PAIZ w latach 1989-1997 bezpośrednie inwestycje zagraniczne w Polsce wynosiły ogółem $20587 \mathrm{mln}$ USD, w tym inwestycje powyżej $1 \mathrm{mln}$ USD 17705 mln USD. Spośród inwestycji powyżej $1 \mathrm{mln}$ USD $11155 \mathrm{mln}$ USD, tj. 63\% przypadało na przemysł, w tym $11042 \mathrm{mln}$ na działalność produkcyjną, 96,5 mln na zaopatrzenie w energię elektryczną, gaz i wodę i zaledwie 16,2 mln na górnictwo i kopalnictwo. W przemyśle najwięcej, bo $3270 \mathrm{mln}$ USD, tj. 29,3\% inwestorzy zagraniczni ulokowali w przedsiębiorstwach produkujących artykuły spożywcze, napoje i tytoń, $2511 \mathrm{mln}$, tj. 22,5\% w przemysł środków transportu, $1158 \mathrm{mln}, \mathrm{tj} .10,4 \% \mathrm{w}$ przemysł papieru i działalność wydawniczą i poligraficzną, $1087 \mathrm{mln}$, tj. 9,7\% w produkcję chemikaliów i wyrobów chemicznych, $971 \mathrm{mln}, \mathrm{tj} .8,7 \%$

w przemysł mineralny, $664 \mathrm{mln}$ USD, tj. 5,8\% w produkcję urządzeń elektrycznych i optycznych, a resztę w przemysł metalurgiczny, metalowy, drzewny, lekki i pozostałe gałęzie.

Największy udział w bezpośrednich inwestycjach zagranicznych w Polsce ma kapitał USD, na który przypadało w końcu 1997 r. 17\% ich wolumenu. Dalej szli w kolejności inwestorzy z Niemiec - 11,9\%, koncernów ponadpaństwowych - 9,3\%, Włoch - 9,2\%, Francji $-9,1 \%$, Holandii - 6,9\%, Korei Płd. - 6,1\%, Wielkiej Brytanii - 5,6\%, Austrii $3,7 \%$, Szwecji - 3,2\%, Szwajcarii - 2,5\%, Australii - 2,1\%. Udział pozostałych inwestorów z 20 innych krajów wahał się od $0,1 \%$ do $1,7 \%$.

Ze względu na dane zestawione przez PAIZ według siedzib firm zagranicznych, a nie według faktycznego miejsca lokalizacji inwestycji, nie udało się w opracowaniu dokładnie ustalić wielkości inwestycji w poszczególnych województwach. Na podstawie szacunków można stwierdzić, że około 1/3 wszystkich inwestycji zagranicznych zrealizowanych w przemyśle na obszarze Polski do końca 1997 r. skupionych zostało w województwie warszawskim.

Największymi inwestorami zagranicznymi w przemyśle Polski wg stanu na dzień 31 XII 1997 były firmy: 1) Fiat z Włoch - 1142 mln USD, 2) Deawoo z Korei Płd. - 1011 mln USD, 3) Pepsico z USA - $412 \mathrm{mln}$ USD, 4) JPC z USA - $350 \mathrm{mln}$ USD (przemysł pap.), 5) Coca-Cola Amatil z Australii - 285 mln USD (prod. urządzeń energetycznych), 7) Philip Morris z USA - 202 mln USA (przem. tytoniowy), 8) Nestle ze Szwajcarii - 248 mln USD (prod. żywności), 9) Remtsma-Zigaretten Fabriken z Niemiec - 226 mln USA i 10) Sain Gobain z Francji - 220 mln USD - prod. szkła i materiałów izolacyjnych.

\section{ZAKOŃCZENIE}

W konkluzji przeprowadzonych badań należy stwierdzić, że w rozpatrywanej dekadzie transformacji gospodarki polskiej (1988-1998) gruntownym przekształceniom uległa również struktura własnościowa działalności przemysłowej w naszym kraju. Wyrażają się 
one głównie w osiągniętym wysokim poziomie sprywatyzowania tej działalności, który przekroczył w 1998 r. 70\% ogólnej liczby pracujących (w końcu 1998 r. sektor prywatny skupiał tylko $12,7 \%$ pracujących w przemyśle na obszarze Polski).

Rezultaty procesu prywatyzacji są przestrzennie bardzo silnie zróżnicowane. W większości województw, zwłaszcza słabo i średnio uprzemysłowionych znajdujących się głównie we wschodniej i północnej części kraju, z powodu osiągnięcia już przez te województwa bardzo wysokiego lub wysokiego stopnia sprywatyzowania przemysłu możliwości dalszej prywatyzacji są bliskie wyczerpania. Z kolei w większości województw wysoko i bardzo wysoko uprzemysłowionych, zwłaszcza tych, w których wielką rolę odgrywają wielkie fabryki oraz przemysł wydobywczy istnieją w dalszym ciągu wielkie możliwości prywatyzacji działalności przemysłowej. Dotyczy to w szczególności najwyżej uprzemysłowionego województwa katowickiego, w którym sektor państwowy zatrudnia nadal ponad $50 \%$ pracujących w przemyśle, tj. ponad 300 tys. osób. Stosunkowo duże możliwości dalszej prywatyzacji istnieją również w innych województwach: warszawskim, bielskim, krakowskim, gdańskim i opolskim, w których sektor państwowy skupia jeszcze od 30 tys. do 60 tys. pracujących w przemyśle. Dosyć znaczne możliwości prywatyzacji sektora państwowego występują również w dalszych województwach: lubelskim, kieleckim, piotrkowskim, tarnobrzeskim, legnickim, łódzkim, poznańskim, rzeszowskim, jeleniogórskim, szczecińskim i radomskim, w których sektor państwowy skupia jeszcze od 21 tys. do 30 tys. pracowników przemysłowych.

Dalsza prywatyzacja przemysłu do pożądanego racjonalnego poziomu wymagać będzie również w XXI w. dużego wysiłku finansowego mieszkańców kraju i współdziałania inwestorów zagranicznych w tej dziedzinie.

\section{Literatura}

Biskup J., 1997, Bezpośrednie inwestycje zagraniczne na koniec 1995 r. (wedtug danych GUS i NBP), [w:] Inwestycje zagraniczne w Polsce, IKiCHZ, Warszawa, s. 81-102

Domański B., 1999, Structure, regional distribution and selected effects of foreign direct investment in Polish manufacturing in the 1990, Wirtschafts-geogr. Studien, Wien, s. 71-88

Durka B. red., Inwestycje zagraniczne w Polsce, IKiCHZ, Warszawa, z lat 1990 i 1998

Lista 500 w r. 1998, "Rzeczpospolita" z 6 V 1999

Materiały PAIZ (Państwowej Agencji Inwestycji Zagranicznych) z lat 1996-1998

Materiały Departamentu Pracy GUS z lat 1988-1991

Olesiński Z., Pac-Pomamacki R., 1998, Działalność dużych inwestorów zagranicznych w Polsce, [w:] Inwestycje zagraniczne w Polsce, IKiCHZ, Warszawa 1998, s. 96-115

Pracujacy w gospodarce narodowej, GUS, Warszawa, z lat 1995-1999

Ranking 500 największych polskich firm prywatnych sektora produkcji, "Home and Market" z maja 1999 r., s. 86-116

Rocznik Statystyczny, GUS, Warszawa, z lat 1989-1999

Rocznik Statystyczny Przemysłu, GUS, Warszawa, z lat 1989-1999

Roczniki Statystyczne województw, GUS, Warszawa, z lat 1989-1999

Slenczek M., 1997, Pochodzenie $i$ wielkość inwestycji zagranicznych w Polsce w latach 1989-1996, "Czas. Geogr." vol 68, nr 3-4, s. 373-382 
Zagoździńska J., 1998, Podmioty z udziałem kapitału zagranicznego w Polsce w latach 1993-1996 (wg danych GUS), [w:] Inwestycje zagraniczne w Polsce, IKiCHZ, Warszawa 1998, s. 63-95 Zatrudnienie w gospodarce narodowej z lat 1989-1999, GUS, Warszawa 